RESIDENT

\& FELLOW

SECTION

Section Editor

Mitchell S.V. Elkind,

MD, MS

Atma Ram Bansal, MD

Neeraj N. Baheti, MD

Chaturbhuj Rathore,

MD

Chandrasekharan

Kesavadas, MD

Address correspondence and reprint requests to Dr. C. Rathore, Department of Neurology, Sree Chitra Tirunal Institute for Medical Sciences and Technology, Trivandrum, Kerala, India 695011

cbrathore@rediffmail.com

Teaching NeuroImages:

\title{
Adrenoleukodystrophy presenting as raised intracranial pressure
}

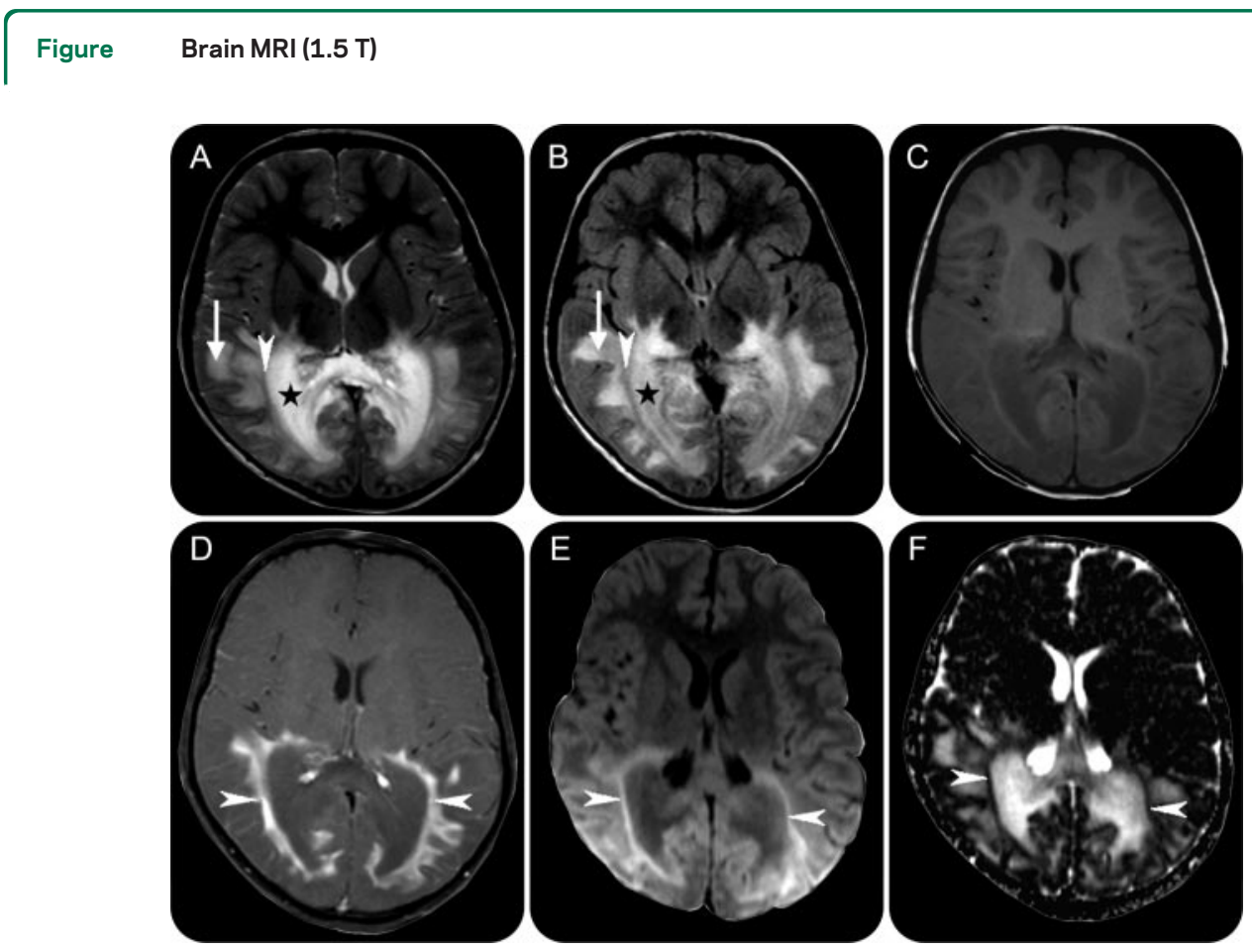

Axial images showing symmetric bilateral parieto-occipital white matter changes with local mass effect. (A, B) T2-weighted and fluid-attenuated inversion recovery images show regions corresponding to the 3 classic histopathologic zones of

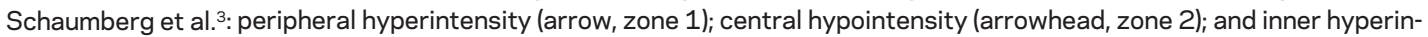
tense zone (asterisk, zone 3). Areas with active inflammation (zone 2 and adjacent part of zone 1 ) show contrast enhancement ( $C, D$; arrowhead) and diffusion restriction (E, F; arrowhead).

A 7-year-old boy presented with acute onset headache, vomiting, and visual deterioration 2 weeks previously without any cognitive or behavioral changes. Optic fundi showed papilledema, and there were no pyramidal signs or gait disturbances. The remainder of the neurologic examination was normal. CSF protein was $174 \mathrm{mg} / \mathrm{dL}$. Although MRI features (figure) were consistent with adrenoleukodystrophy (ALD), the atypical presentation prompted consideration of alternate diagnoses and therapies. Subsequent progressive vision and hearing loss, bilateral pyramidal signs, and elevated plasma very-long-chain fatty acids confirmed ALD.

Childhood cerebral ALD can present acutely, but rarely with raised intracranial pressure. ${ }^{1}$ Elevated CSF protein and mass effect due to fulmi- nant demyelination and inflammation is a possible cause. Familiarity with atypical clinical courses ${ }^{2}$ and classic MRI features may avoid unnecessary investigations and delayed diagnosis.

\section{REFERENCES}

1. Chaves-Carballo E, Frank LM, Chrenka BA. Increased intracranial pressure in adrenoleukodystrophy. Arch Neurol 1984;41:339-340.

2. van Geel BM, Assies J, Wanders RJ, Barth PG. X linked adrenoleukodystrophy: clinical presentation, diagnosis, and therapy. J Neurol Neurosurg Psychiatry 1997;63: $4-14$.

3. Schaumburg HH, Powers JM, Raine CS, Suzuki K, Richardson EP Jr. Adrenoleukodystrophy: a clinical and pathological study of 17 cases. Arch Neurol 1975;32: 577-591.

From the Departments of Neurology (A.R.B., N.N.B., C.R.) and Imaging Sciences \& Interventional Radiology (C.K.), Sree Chitra Tirunal Institute for Medical Sciences and Technology, Trivandrum, Kerala, India.

Disclosure: The authors report no disclosures. 


\section{Neurology}

\section{Teaching NeuroImages: Adrenoleukodystrophy presenting as raised intracranial pressure}

Atma Ram Bansal, Neeraj N. Baheti, Chaturbhuj Rathore, et al. Neurology 2010;74;e93

DOI 10.1212/WNL.0b013e3181e042b2

\section{This information is current as of May 24, 2010}

\section{Updated Information \& Services}

References

Citations

Subspecialty Collections

Permissions \& Licensing

Reprints including high resolution figures, can be found at: http://n.neurology.org/content/74/21/e93.full

This article cites 3 articles, 1 of which you can access for free at: http://n.neurology.org/content/74/21/e93.full\#ref-list-1

This article has been cited by 1 HighWire-hosted articles: http://n.neurology.org/content/74/21/e93.full\#\#otherarticles

This article, along with others on similar topics, appears in the following collection(s):

\section{All Clinical Neurology}

http://n.neurology.org/cgi/collection/all_clinical_neurology

All Demyelinating disease (CNS)

http://n.neurology.org/cgi/collection/all_demyelinating_disease_cns Leukodystrophies

http://n.neurology.org/cgi/collection/leukodystrophies

Metabolic disease (inherited)

http://n.neurology.org/cgi/collection/metabolic_disease_inherited

MRI

http://n.neurology.org/cgi/collection/mri

Information about reproducing this article in parts (figures,tables) or in its entirety can be found online at:

http://www.neurology.org/about/about_the_journal\#permissions

Information about ordering reprints can be found online:

http://n.neurology.org/subscribers/advertise

Neurology ${ }^{\circledR}$ is the official journal of the American Academy of Neurology. Published continuously since 1951, it is now a weekly with 48 issues per year. Copyright . All rights reserved. Print ISSN: 0028-3878. Online ISSN: 1526-632X.

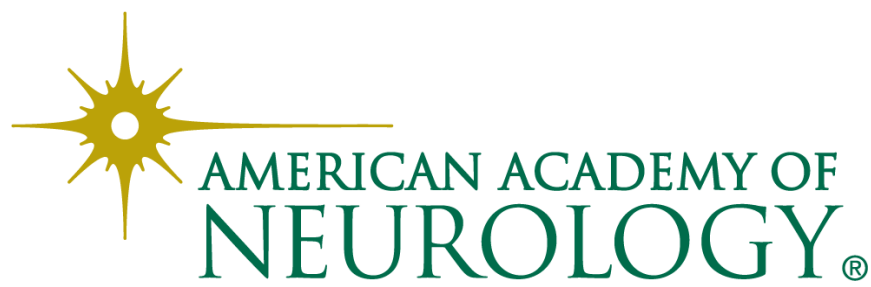

